\title{
The Effect of Labor Exploitation on Children's Psychological Wellbeing in Woldia Town Primary Schools: Implication for Intervention
}

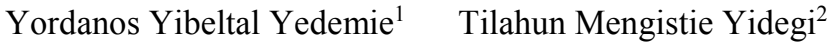 \\ 1.Bahir Dar University, College of Education and Behavioral Sciences, Department of Psychology, Bahir Dar, \\ Ethiopia \\ 2.Woldia Teacher Education College, Department of Chemistry, Woldia, Ethiopia
}

P.O. Box: +25179

\begin{abstract}
The main objective of the study aimed at assessing the effect of child exploitation on children psychological well-being Woldia town seven primary schools. Qualitative and quantitative are employed. That is, descriptive survey used to the study. The study used questionnaire and interview as data gathering instruments. Hence, data gathered through questionnaire from students and teachers that are selected through comprehensive sampling. The data analyzed through percentage and one-sample t-test. Then, the finding of the study revealed that the major labor activities in which children are engaged in Woldia town include shoe shining, selling lottery tickets, selling food/drinks/ kollo, and assisting taxi drivers (woyala). Most of the child labor exploitation in the study came from regions to look for job, due to conflicts at home, early marriage and divorce, Poverty, death of one or both parents, child trafficking, high repetition rates, drop out from school and lack of awareness about the consequence of being engaged in labor exploitation are key factors that push children to be involved in different work. The major problems that have been faced by children engaged in labor exploitation include among others: frustration, low self-esteem, self-perception, learning participation, attitude of the community and intimacy on parents. Lobbying and advocacy for the drafting and enactment of laws and policies for the prevention of child labor.
\end{abstract}

Keywords: Child exploitation; Consequence; Psychological well-being; Intervetion; primary schools

DOI: $10.7176 /$ RHSS/10-15-02

Publication date:August $31^{\text {st }} 2020$

\subsection{Introduction}

School is the best place to child loabor and this movement addresses the general public, decision makers, school consumers and corporate sector to create awareness to join hands for the elimination of child labor. Under the slogan: "Stop Child Labor - School is the Best Place to Work" the movement promotes education as a strong tool for tackling the child labor. The movement urges all governments, non-governmental actors, corporate bodies, and other prominent stakeholders to act for the elimination of all kinds of child labor. In doing so, it is possible to ensurethat children get proper formal education(People in need Ethiopia, 2009, 4).

Children do not have well developed physical, moral and psychological to have unnessasery situation for their life and protect his/her self from different challenges. Hence, they need special support and protection. As their early age, many children face with different problemsand challenges. Hence, the rightactivities of other person areto help them becausechildren donotprotecthis/her self properly. Children personality development totally protected from labor exploitation in order to produce well mannered or disciplined society and good citizenship in one country. So, children should get special attention and protection starting from today. In relation to this, studies that have been done on child lobar explotation suggested that the community should give care for children self right to choice to live long, to have peace, education, psychological wellbeing (Situation of Child Labor Assessment, 2006).

Child labor is a major international problem mainly from psychological and socio economic roots. There is international agreement that the elimination of child labor is essential for thewellbeing of society. Thisbelief has received universal recognition as discovered by the common approval of the 175 member states ofthe International Labor Organization of Convention 182. However, child labor is still seen in many developing nations. This gives an insight into this deeplyawful practice, and the scarringeffects it can have on children and society as a whole.In developing countries,like Ethiopia where the worst forms of childlabor such as shoe shining, selling lottery tickets, selling food/drinks/ kollo / kubet, assisting taxi drivers (woyala) and caring material are widelyobserved(Children's Rights,1995).

Taking aggressive action to eliminate this child labor is difficult at national level where 75 percent of the population lives in rural areas, most often stricken by poverty. Children are viewed as a form of economic security in this isolated setting, necessary to help supplement their families' income. Parents often sacrifice their children's education, as offspring are often expected to uphold their roles as wage-earning members of their 
family (Children's Rights, 1995).

In some developing countries, womenare denied formal education is brought up only to perform household tasks since a very young age. Such a society believes that an educated woman will not fit into the traditional role of a home maker and bear children. This notion fuels child laborand young girls thus get will be pushed into doing manual house work from an early age (Children's Rights Report, 2007).

There are local and international NGOs engaged the rehabilitation as well as prevention of child labor. For example, African Network for the Prevention and Protection against Child Abuse and Neglect (ANPPCANEthiopia Chapter) works with a mission to contribute to the prevention of child maltreatment and protection of children against abuse, neglect and exploitation through increasing public awareness on child abuse and child rights, promoting child participation and providing rehabilitation services for victim children and their families. However, there are only six percent of the needy children in Bahir Dar that have the chance to obtain essential services (Yang, 2004).

The major role of governmental, local and international NGOs is to prevent and to protect children from exploitation and theier major activities include counseling services, organizing special events for raising the awareness of the community, stage educational/entertaining programs through drama/ puppet shows, training of peer educators, developing and distribute leaflets, booklets and other related issues, providing washing and laundry facilities and library and recreational materials, providing washing and laundry facilities and library and recreational services (Save the Children and UN Convention, 1997).Hence, the current researcher would like to assess the effect of labor explotation on children's paycholgical well being in Bahir Dar city primary schools.

The problem of child labor is widely observed inEthiopia especially in the informal sectors. This might be related to several factors like poverty, psychological wellbeing, inequality, socio-economic vulnerability, inadequate/inappropriate education opportunities and cultural norms and values.Today, approximately 15.5 million children, many as young as fourteen, are involved in child labor in Ethiopia. That is, child labor harms them or keeps them from attending school. It involves work by children under conditions that are hazardous, illegal, or exploitive (University of Iowa Labor Center, 2010).From these, we can understand that there are large numbers of children who are forced to labor market. Hence, the researchers would like to assess the effect of labor explotation on children psychological well being in Bahir Dar city praymary schools.

\section{Method}

As the study seeks to assess on the effects of labor exploitation on children self- perception, the effects of labor exploitation on children learning participation, the effects of labor exploitation on children attitude to the community, and differentiates the effect of labor exploitation on children intimacy on parents taken in to consideration. To answer the research questions, qualitative and quantitative method was used for this study.

About study participants, there are seven primary schools in Woldia town administration. Hence, all schools are selected through purposeful sampling. Out of these schools, those who are found in grade 7 and 8 grade students because most of these children are found to be high chance to be forced to labor explotation than early grades as country report. Hence, they are selected through purposeful sampling. Accordingly, the participants of the research were Woldia town of seven primary school children who grade 7th and 8th faced with labor exploitation and subject teachers were used as the population of the study.

The total number of grade $7^{\text {th }}$ and $8^{\text {th }}$ students who are found in the age of 10 up to 18 years old are 105 in the selected seven schools. Hence, they are selected through comprehensive sampling. Besides, there are also 39 teachers who are teaching grade 7 and 8 during this academic year. Hence, they are selected in terms of comprehensive sampling.

In order to collect the data, the researchers used questionnaire and interview for data collection instrument to get reliable and valid information.

The collected data from the questionnaire and interview were organized quantitatively and qualitatively. Finally, the results obtained from each instruments that are organized both qualitatively and quantitatively are presented by comparing and contrasting to reach the conclusion and possible solutions were analyzed and discussed as follows in chapter four. The data collected were cleared, tabulated and made ready for analysis using appropriate statistical techniques descriptive statics mainly percentage and t-test wasused, qualitative techniques will be employed and use graphs to analysis the data. 


\section{Results}

1. The students' response for general items

Table 1. Descriptive statistics for students' one-sample t-test statistics

\begin{tabular}{|l|l|r|r|r|}
\hline Noo & General items & \multicolumn{1}{|c|}{ t-test } & Std. Deviation & \multicolumn{1}{c|}{ Mean Difference } \\
\hline 1 & Self perception & 76.224 & 2.714 & 20.190 \\
\hline 2 & Learning participation & 104.008 & 2.364 & 23.990 \\
\hline 3 & Attitude of the community & 90.650 & 2.471 & 21.857 \\
\hline 4 & Intimacy on parents & 76.333 & 2.545 & 18.962 \\
\hline
\end{tabular}

In order to examine the over all or general psychological wellbeing of children levels were far below the expacted mean in self perception, learning participation, attitude of the community and intimacy on parents to show the effect of children labor exploitation.

Table 2. Self perception of descriptive statfvstics for students' one-sample t-test statistics

\begin{tabular}{|l|l|r|r|r|}
\hline No & \multicolumn{1}{|c|}{ Items } & t-test & \multicolumn{1}{|c|}{$\begin{array}{c}\text { Std. } \\
\text { Deviation }\end{array}$} & \multicolumn{1}{|c|}{$\begin{array}{c}\text { Mean } \\
\text { Difference }\end{array}$} \\
\hline 1 & The work to develop self confidence. & 37.085 & .091 & .118 \\
\hline 2 & The work to increase self initiatives. & 27.259 & .093 & 3.381 \\
\hline 3 & $\begin{array}{l}\text { Play with friends to show different Behavior } \\
\text { (aggressiveness). }\end{array}$ & 36.294 & 3.381 \\
\hline 4 & To happy done this work. & 37.878 & .089 & .102 \\
\hline 5 & Done this work restless and unpowerful. & 39.056 & .093 & 3.371 \\
\hline 6 & Done the work flow things response his /her self esteem & 30.773 & 2.876 \\
\hline
\end{tabular}

Scored on a 5 point scale ranging from "strongly agree" (5) to "undecided" (1)and the result was reported that they disagree in their effect ofSelf perception of children show labor exploitationof question" Done the work flow things response his /her self esteem"(mean=2.876, expected mean 3,SD=0.093,t-test $=30.773$ ) in the other side children agree of question" Done this work restless and un Powerful" (mean=3.971, expected mean $3, \mathrm{SD}=.102$, t-test $=39.056)$ to show their effect of labor exploitation in Self perception of children.

Table 3. Learning participation of students'

\begin{tabular}{|c|c|c|c|c|}
\hline NO & Items & t-test & $\begin{array}{c}\text { Std. } \\
\text { Deviation }\end{array}$ & $\begin{array}{c}\text { Mean } \\
\text { Difference }\end{array}$ \\
\hline 1 & The work is affect on done homework. & 36.202 & 1.068 & 3.771 \\
\hline 2 & The work is done to have enough participation in the class. & 34.372 & .971 & 3.257 \\
\hline 3 & The work to decrease studying motivation. & 44.008 & .918 & 3.943 \\
\hline 4 & Most of the time depressed in the class. & 41.308 & .964 & 3.886 \\
\hline 5 & The work to crate frustration and anxiety on learning time. & 32.977 & 1.201 & 3.867 \\
\hline 6 & The work to improve willingness to learning. & 29.934 & .893 & 2.610 \\
\hline 7 & To feel do not rank in school award. & 30.358 & .897 & 2.657 \\
\hline
\end{tabular}

The result was reported that they disagree in their effect of learning participationof children show labor exploitation of question" Theworktoimprovewillingness to learning." (mean $=2.610$, expected mean $3, \mathrm{SD}=.893$, t-test $=29.934)$ in the other side children wereagree of question" The work to decrease studyingmotivation." $($ Mean $=3.971$, expected mean $3, \mathrm{SD}=.918$, t-test $=44.008)$ to show their effect of labor exploitation inLearning participationof children.

Table 4. Attitude of the community of descriptive statistics for students' t-test statistics

\begin{tabular}{|l|l|r|r|r|}
\hline NO & \multicolumn{1}{|c|}{ Items } & t-test & \multicolumn{1}{|c|}{ SD } & Mean Difference \\
\hline 1 & The work to create good attitude on parents. & 29.783 & 1.042 & 3.029 \\
\hline 2 & The work to decrease parents liking. & 29.689 & .999 & 2.895 \\
\hline 3 & The work to increase love on parents. & 33.005 & .813 & 2.619 \\
\hline 4 & Done this work forced by parents, helpers, and other. & 32.716 & 1.110 & 3.543 \\
\hline 5 & Done the work easy to solve family problems. & 38.158 & 1.074 & 4.000 \\
\hline 6 & The work creates good relationship with parents. & 28.737 & 1.026 & 2.876 \\
\hline
\end{tabular}

The result was reported that they disagree in their effect of attitude of the communityof children show labor exploitation of question" The work creates goodrelationship with parents" (mean=2.876, expected mean $3, \mathrm{SD}=$ 1.026 , t-test $=28.737$ ) in the other side children wereagree of question" The work to decrease studying motivation." mean $=4.000$, expected mean $3, \mathrm{SD}=1.074$, t-test $=38.158$ ) to show their effect of labor exploitation in Attitude of the communityof children. 
Table 5. Intimacy on parents of descriptive statistics for students' t-test statistics

\begin{tabular}{|l|l|r|r|r|}
\hline Nó & \multicolumn{1}{|c|}{ Items } & t-test & \multicolumn{1}{|c|}{$\begin{array}{c}\text { Std. } \\
\text { Deviation }\end{array}$} & $\begin{array}{c}\text { Mean } \\
\text { Difference }\end{array}$ \\
\hline 1 & The work to pass right time on village children. & 31.932 & .895 & 2.790 \\
\hline 2 & $\begin{array}{l}\text { Done the work to show feeling of inferiority in the } \\
\text { community. }\end{array}$ & 34.914 & 1.188 & 4.048 \\
\hline 3 & Done the work Insult by friends. & 44.474 & .981 & 1.175 \\
\hline 4 & Helping and working each other with friends. & 33.308 & 1.078 & 4.257 \\
\hline 5 & Done this work to have stigma and discrimination. & 39.380 & .903 & 3.819 \\
\hline 6 & After school to have playing time. & 31.774 & 4.143 \\
\hline
\end{tabular}

The result was reported that they disagree in their effect of Intimacy on parentsof children show labor exploitation of question" The work to pass right time onvillage children" (mean=2.790, expected mean 3, $\mathrm{SD}=.895$, t-test $=31.932$ ) in the other side children were agree of question" Done the work Insult by friends" mean $=4.257$, expected mean $3, \mathrm{SD}=.981$, t-test $=44.474$ ) to show their effect of labor exploitation in Intimacy on parentsof children.

Figur 1. Intimacy on parentsmean graph

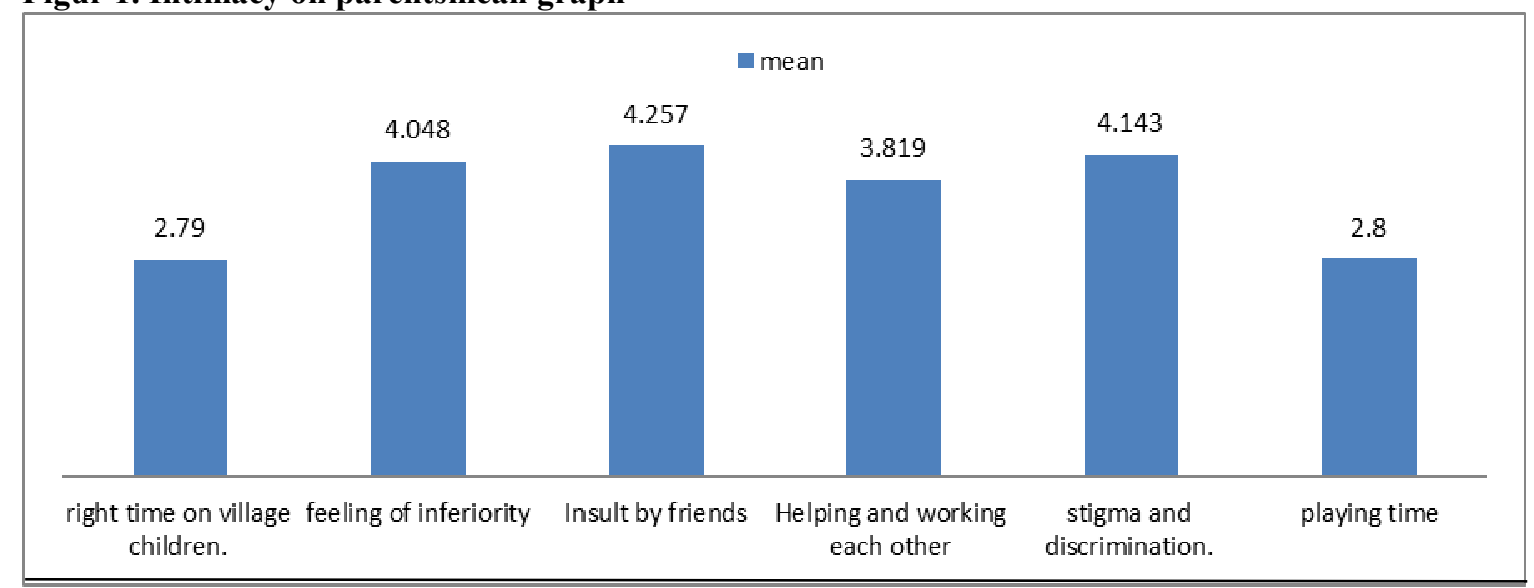

Generaly, the finding showed that indescriptive statistics of students' one-sample t-test statistics their effect of labor exploitation in self perception, learning participation, attitude of the community and intimacy on parents totally effect on children psychological wellbeing.

\section{The students'and teachers' response on open ended questionnaires}

In the teaching learning process, teachers occupy the centeral and critical position. The success and failure of learning and achievement of educational goals depend to a greater extent on teachers. In this section discussed the most critical factors that have abearing on students' academic, social and psychological development.

Student responds "How many time stay in the work? Write working days?" stated in this open ended question work over 8o'clock after school time Monday to Friday and Saterday and Sunday work the whole day 1o'clock at the morning to 12 o'clock at the evening in addition to this work break time and summer work with out rest. The above respondent of student shows that $80 \%$ of respondent children work over 80 'clock in aday to be against the right of children.

"What kinds of challenge face in the work?" Respondent listed various challenges passed and bad practices have in the work that is:- adicted by alcohol and chate, stolen money and materials by gangster,insult by different people,sexual harasement and abuse for illegal person, buy the materials but donot paid,the problem of transport to sell differene materials around the kebele then restless and unpowerful lastly sleep with out doing home work and at the morning frustration and freely goto school.In the respondent answer show children effect on done the work various psychological, physical,mental wellbeing.

The teacher lists the challenge of students to learn and behave badthings like:punished by adolescence,lack of working place,lack of money, lack of time tostudy, negative and less attitudes of the communities ,absence and late in school,family economically poor and do not educated,hungry,restless,boaring at learnig time ,do not commited for the people seen like robbery,affect self confidence because the community forced by different work to show the response of teachers students affect on selfperception and learning participation

"How get less price work with equally with adult worker?" to response answer children paid less price because of to think children for age and physicaly,mentaly undeveloped response $42.8 \%$ of them, problem of the attitudes of the empiloyers response $37 \%$ of them and forced the right of children ,to think out of humanity to paid different to adults, to think no option to get other work response $12.2 \%$ of them and do not ask why to pay 
less to adult and opposers for children right response $8 \%$ of them.In this response show that children do not keep his/her right and the community un developed attitudes about children care and suporet then to develop low self perception,wary about the community then psychologically affected.

"To have satisfactions get money or not? Why?"in the questions student response $78.4 \%$ of them unsatisfied in the work because not enough to cover daily expenses to buy only pen, exercise book, some times cloth and shoes. some student answer tohave satisfiedresponce $21.6 \%$ of them because of toget income form my family.the response show that mostly unsatisfided with the work unhappy for the work but do not take right time to the family.

To suffer related to class students to learn with out other work and do not work properly, some times do not get in come to be angry and heartly feel so to affect on his/her psycholodical wellbeing of children. Student stated that my mother have enough in come to happy and learn properly with out work but dipressed and do not learn to think badly. The teacher stated that students show psychologically inferiorefor class student and specialy show his/her self as aproblematic person then effect on self confidence and self esteem thinking because the situation related toeach other.To show the response children affect on psychological development today and at the later stages of development then to work in this time to skillfull children as the case of situational work.student learning, playing stages out of the children or frindes to lack moral satisfaction, bad image for the community, stigma and discrimination applied for the children.

Student stated that labor exploitation regularly applied for parents $29.4 \%$, employers $45.7 \%$ (to haveincome toused childrens labor special profite highly affected), helper $11.3 \%$, and nabor $13.6 \%$ (to have promise for the family to learn children but in the other side to work strictly then to be exploited) to forced in this work to cover different out come and to solve family problem. Totally, different from the degree of exploitation but all are exploitated childrens for various situations.

Student response that done in this situation mentally, psychologically, physically harassed and stressed highly on work to with drown for learning do not targate the goal of his/her life objectives to forced different activities traind and skillfull for various stakeholder face with strightism after this take crime,addiction, withdrown for learning. To reduce willingness tolearn, reduce self-confidence, self-perception, and self-esteem and morally dissatisfied.

The teacher response in student's day to day activity (portifolio) information listed continousely not done home work, test and different assessment passed, constantly late and absent in the class, some times withdrawn in learning, most of the time in the class highly depressed and passive listener and new for unlearned topicspass do not live in the class, do not participate in the teaching learning process.

"How do you think the resilence capacity of children in the work?" response teachers the age of children is less between 10 to 14 do not resilence for the work over for the children capacity and do not train different stakeholders over coming effects and faced with different accident and do not resilence.weak for psychologically wellbeing and in the school do not have guidance and counceling teachers to up grade student's capacity and solve different problems.

\section{The students'and teachers' response on interview questions}

In addition to those effects that we presented using qualitative approach the study also employed interview questions to dig out those effects that may account for children labor exploitation on psychological wellbeing.

"How to get out of this work?" Student stated thattogetalternativework, donot have money tobuy exercise book,pen,cloth,shoes,properly tolearen and participate in the lesson,play together with friends, enough time for clothness to parentes and love parents, avoid restlessand unpowerful physical harassment to have time to make up class,reading and studing time, do not insultby others or frindes but do not have money.Studentes response show out of this work improve learning participationand to have good attitudes to the community and love on parentes because money time to pass his/her parentes then psychological wellbeing of students affect by labor exploitation.

The teacher response student to have right personality to obtain moral, psychological satisfaction, tolive best life and mentally machured to identify different situation,to be self-confidence,self-initative,self-esteem person things work his/her asumtion not forced by others ,manage his/her life properly ,to have great place for learning ,playing,studing,reading,live with parentes then tohave positive attitude for learning participation intimate on parentes ,self-perception and attitude of the community to caltivate the right of children to learn and developed mentally ,psychologically developed.To find organizationto alivate this situation to focuse on the learning process to sit the corener stone of children developmental ages.As the response of teacher "How to get out of this work?" highly focused on student learning participation and psychologically developed to show the effect of labor exploitation.

"What kind of situation forced in this activity?" the student and the teacher interviween toresponce to obtain money and to help my family by material and money, live alone with out parentes so to manage myselves to forced in this work live with to have God blasing persons to encourage the work.Family less economical statues 
to forced in this work to prevente this situation by the help of getting income.Obstacle for learning and do not have family tomanage learning and life .To solve his/her problems and family divores,poorsittuation of the family ,to get money forced with the work and to avoide the work to have grate headacke for children to habite this situation to sweat the income finally to with drown the school the load of work and high value to getting money.

Do not help parentes because economically developed family to wear good cloth and shoes and learn properly. To get life easily to learn properly and learn with out any challenge not think others because this stage is not the stage of work but the stage of playing and learning stages. To think infererity for my freind and safer from different activity to do properly then my self perception is low.

"To train and help teachers and stakeholders' labor exploitation affect?" Student said that to help teachers to learning with out any punishment and orphan's children help by the school to get different materials. Do not helping and traing for other stakeholders' simply list the name and do not have any helping activity but tankyou teacher and school worker tothink heartly for his/her improvement.

Most of the time late and absent in school because of working situation and in the morning pick up lately in sleep do not get on time in the class. Do not right time for learning late and absence most of the time in the class. The response to show that no place to learning the main task is working but learning is profitable activities to think then this is wrong assumption or ideas of children because in this age the first activities is learning to develop mental and psychological active.

The mood of children at the time of helping in educational case less do not listen most of the time like body is present mind is absent to think after school work do not emotionally active to effect of his/her psychological wellbeings.

"What kind of protection used to avoide children labor exploitation?"Teacher response to find organization to work around to children care and support and not only to train childrens continuious life skill trainings to have resilence the effect of labor exploitation but also parents and the community. Toconstruct project for children, learn with out challenges and to crate good citizens for the societies.

"How do you see students at the time of learning to show feeling of inferarity?" Teacher said that student to show inferiority in the class because of do not know the topic of learning and fractirated. Student to show inferiority do not work his/her task properly saffer for this situation. Generally,lack of some thing aperson saffer and frastirated as this case show the level of inferiorities.

Figur 2. Summary chart

\section{Psychological wellbeing}
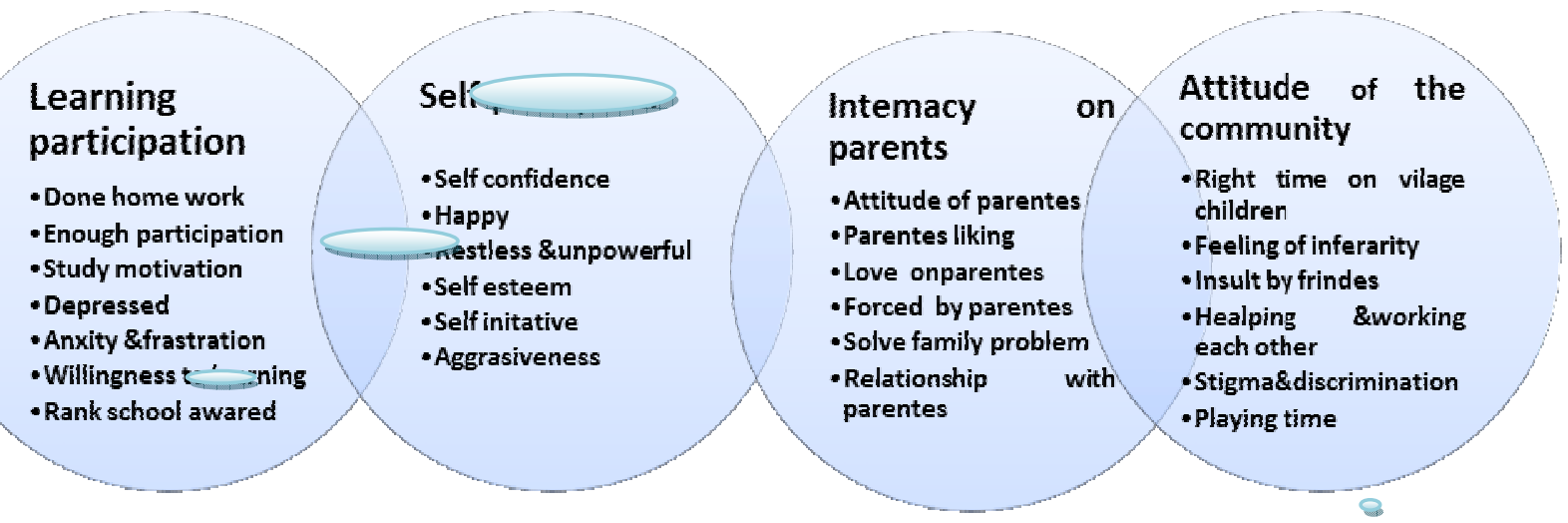

Labor exploitatio 


\section{Discussion}

\section{The effects of labor exploitation on children self perception}

Like in many other sub-Saharan African countries, a large number of children in Ethiopia join the labor force usually below the age of 15 . This ranks the country among one of the countries with highest rates of child labor in the world. A survey conducted in 2001 has reported that one-half of all Ethiopian children within the age of 5 to 14 years were engaged in one or another form of child labor (Save the Children Finland, 2008).

One of the investigator Eurusalem university Hibru language researcher Asher Bin Ariyhe "the activity takesplace developing countries education is vital and do not get easly, education it self and happy situation" said. The study greate contributionin the future for country policy makers and organization work with children like care the children to have great in put. "Stages of children see but also its own way not onlythe briged of adult hood" said the resarchers. The study contains Algeria, Nepal, South Africa and Ethiopia kinds of country children pass time done different work but Germony Turki and South Koria children pass time our selves with done our work (Kumneger,2007).

\section{The effects of labor exploitation on children learning participation}

Students' previous academic background, their expectations to wards success, exposures to early childhood education, motivation to wards learning and reading skills in early years determine later academic performance very much. Reading development of students in elementary schools significantly influences students' interest, motivation, and confidencein schools and learning.

Similarly, the 2002 national survey on Child Labor by the Ethiopian Central Statistics Agency (ECSA) indicates that $33 \%$ of the total child population in the age group of 5-7 attended formal schools while 5\% of children in the same age group attended informal (religious) schools. The survey has shown a disturbing figure of $56 \%$ of children in that age group never attended school neither formal nor non-formal. Drop out rate in the survey year was reported $5 \%$ with the rate higher for boys than for girls.

It is clear from the responses above in the survey that child labor plays the major role (combining the percentage of responses under the second, fourth and sixth bullets i.e. about 35.7\%), in depriving most children from schooling. The level of education achieved by child workers is very low. The literacy levels among child domestic workers are low, with many either being illiterate or dropouts from school (UNICEF, 2006). The ILO baseline study revealed that $54 \%$ of the child workers interviewed had completed primary school, $27 \%$ had never been enrolled and $14 \%$ had dropped out of school (ILO, 2003).

Studies reported that children, youth labor exploitation activities are caring materials, selling koolo, selling lottery selling soft, gume, candy $83 \%$ and the age of children 5 to 11 years $72 \%, 12-14$ years $79 \%$ and $15-1885 \%$. Working hour of children 8 o'cloke, $34 \%$ above 8 o'cloke $26 \%$ and $39 \%$ of them donot know working hours. Children work out of the law of work and emplioee and employers policy tohave labor exploited. (Heck, 2007).

One problem of students in schools is getting bored of learning and experiencing afeeling of hopelessness. In the current study, students in the region were founed to have less degree of hoplesness and burnout this implies that the more students feel hopeless about thire futer life in relation to their academic career,the higher is burnout or vise-versa.Further more,other studies revealed that burnout has asignificant negative effect on academic achievement of students(Yang, 2004). The measure of variables implies that hoplesness and burnout were significantly correlated with students' academic related behaviors.

Study behavior normaly entails the ideas of engagement. Those students who have good study habites, skills, attitudes and motivation tend to be involved highly in their academic task. This suggests that active student engagement with the academic task relates significantly and positively with academic performance.

Inrelation to the present study, poor study skills and habites imply that students have problem of managing their time, problems of using aproprate resources, poor reading habites revewing and summarizing of the learned materials, and difficulty of note making, lack of planning and managing ones course work or learning materials. The student in this study reported that their study skills and habites were poor. These poor skills, habites and attitudes undoubtedly interrupt up on the student's academic performances.After conducting ameta-analysis of research on study skill,study habites and study attitudes concluded, studyskills,study habites,study attitudes,and study motivationplay acritical and centeral role in determining students' academic performance(Crede \& Kuncle, 2008:444).

\section{The effects of labor exploitation on children attitude to the community}

Children's Rights will enable researchers, legislators, and academics to compare and contrast how children are treated among the different continents and which policies and laws have had the most profound impact on the younger generations. There has been much progress in the children's rights movement, but more nations must act to protect those who most need it. As a former judge, I saw firsthand how crimes against children affected their future. Children are a nation's future. The best gift we can give to the world is to ensure a safe, healthy, educated, and able future generation. And that's just the way it is. 
Simlarily, the study conducted by Save the Children Denmark on Child Labor in Ethiopia in 2003 shows that nearly $65 \%$ of the working child population in urban areas join the labor market bellow the age of 15 . The interview conducted with the director of FSCE that has rich experience in areas of child labor exploitation reveal the fact that in the rural areas children start working at the age of 4 to support their parents or guardians who usually are preoccupied with the subsistence farming in the extremely fragmented plots of land to sustain the family. The division of labor in rural households therefore is based on age group and gender. What is common according to the informant is all members of the peasant household must have a role even at the expense of the safe growth of children (Sailee, 2011).

\section{The effect of labor exploitation on children intimacy on parents}

Children in rural parts of the country work under hazardous conditions and most commonly for along time. The problem lies however in rural Ethiopia child labor is not considered as hazardous, rather it is considered as one aspect of educating children to socialize in the community and learn the essentials of life skill as they grow adults. In reference to the above argument a research paper presented on ILO annual report entitled "Child Labor in Rural Ethiopia; The Case of Two Peasant Societies; P.29) reads:

"... The work of children in the home or on the family farm under the guidance of parents is an essential part of socialization and development in traditional societies. Where access to education is limited by other factors, and where poverty requires the contribution of children's work, the work of children in traditional family and community occupations may be on balancepositive both in its contributions to family welfare and in the social and psychological development of the child."

Children hold our hopes for a better future. Their status has been a subject of concern for lawmakers, scholars, judges, lawyers, and common citizens. National lawsandregulations as well as international treaties have been dedicated to children with increased interest during the last century. This legal study represents the current status of enforceable laws in a number of countries. Hopefully, this study will help readers have a more detailed understanding of the universal standards on the rights of children tomaketherelationships, between children and their parents, teachers, judges, lawyers, and adults in general, more conducive to a peaceful society.

The other significant factor that forces children to enter into the labor market in their early ages isthe fact that there is low basic service delivery intherural parts of the country especially of primarylevel education. The findings of the study indicate that most children migrate from the rural areas into urban centers aspiring for getting better chances for education.

\section{Conclusion}

The children's rights movement promotes legal protections and safeguards for children, distinct from those of adults. After each world war, international legal instruments increasingly included protection for children across the globe. The League of Nations Declaration of 1924, and the successiveUnited Nations' Declaration of the Rights of the Child in 1959, declared that children need safeguards and protections separate from those of adults and that these protections should begin even before birth.

Many children and youth combine school and part-time work successfully and in the process can acquire self-esteem, develop a sense of belonging to their family and community, gain relevant knowledge and skills as well as gain important life skills such as time and financial management. In our programs, guided by the Convention on the Rights of the Child, the best interests of the child principle and the involvement and participation of children themselves, Save the Children addresses the complexity of broad issue of children and work through an integral approach that combines our expertise in child protection, economic strengthening, health and education to create opportunities for them to become healthy, educated and empowered citizens.

\section{Recommendation}

Based on the result and the conclusion drawn the researcher forwarded the following recommendations.

- To use psychosocial support is the type of support that goes beyond catering for the physical and material needs of the child. Psychosocial support emphasizes one's emotional and spiritual wellbeingand has a bearing on one's psychological health. In other words, it is anongoing process of meeting emotional, social, mental and spiritual needs, all of which areconsidered essential elements for the meaningful and positivedevelopment of the child.

- Victims of child labor are supported by the community in different ways. Mostly skill trainings are provided for the victims to support themselves. The skill trainings are useful strategies to rehabilitate the victims of child labor as they are physically and psychologically affected by the harm inflicted against them by their employers and the society.

- Most stakeholder that are undertaking projects to prevent child labor adopted strategies to aware the society, policy makers and children about the consequences of child labor. As it was indicated one of the aggravating factors for the practice of child labor is misconception and cultural practices. The 
NGOs therefore design awareness raising strategies such as community conversation program, community radio listening groups, media advertising, establishing school clubs and others to raise the level of awareness among thedifferent social groups.

\section{References}

Assessment on Child Trafficking (2004). Multi-Purpose Community Development Project; Addis Ababa

A study on the situation of child labour in Ethiopia: review of existing studies and brief Assessment. People in need Ethiopia July, 2009

Amhara labor and social afiers office (2006). Situation of child labor assessment.Alternative childcare guidelines on community-based childcare and Institutional care service FDRE (2009). Ministry of Women's Affairs Report.

Child Labor in Rural Ethiopia; The Case of Two Peasant Societies.Report of the National Workshop on Child Labor in Ethiopia; ILO, p.29

Child Labor in Ethiopia: Save the Children Denmark (2003). Addis Ababa, PP.23-24

Children's Rights (1995). International and National Laws and Practices Congressional Record 25 July 1995.

Constitution of Ethiopia (1994). Ethiopian Fredera Democrcy Republic Constitution

Crede,M., \&Kuncel, N.R. (2008). study habits, skills, and attitudes: the third pillar supporting collegiate academic performance.Perspectives on psychological science, 3(6), 425-453.

Cresswell, N.D. (2012). Qualitative and Quantitative Research. Sage Publisher: New York:

Debbie Ariyo (2008).Business development expert and International Co-ordinator of AfricansUnite against Child Abuse, a web-based campaign to raise mass awareness about child abuse in Africa.

Heck,R.H. (2007).Examining the relationship between teachers quality asan organizational property of schools and students' achievement and growth rates. Educational administration quarterly,43(4),399-432. http://www.buzzle.com/articles/causes-and-effects-of-child-labor.html

Sideridis, G D., Utiey, C., Greenwood, C.R., Dawson, H., \& Delquardri, J.(1998). An intervention stratagey to enhance spealling performance, social interaction, and decrease in appropriate behaviors of students with mild disabilities and typical peers in aninclusive instructional setting. Resarech inEducation, 59,169-186.

Seleshi Zeleke and Wondimagegnehu Tuji (2008) Situation Analysis of ChildWorkers in Meskan and Butajira Woredas of the Gurage Zone; Savethe Children Finland Ethiopia; Addis Ababa

Sailee Kale (2011).Don't Miss Child Labor Facts Tracking Device for

Tassew W, Bekele T, Nicola J and Alebel B, (2002).Child labour, gender inequality and rural/urban disparities: How CanEthiopia's National Development Strategies be Revised to Address Negative Spill-over Impacts on Child Education and Wellbeing? Young Lives Project; Save the Children UK,

The Federal Democratic Republic of Ethiopia Ministry of Labor and Social Affairs (MoLSA). (2001).Child Labor in Ethiopia Analysis of a Survey Conducted in 2001, by B \& M Development Consultants, March 1, 2006, Addis Ababa, Ethiopia.

University of Iowa Labor Center (2010). 100 Bio Ventures Center, Room W 130, Iowa City IA 52242 -319) 335-4144.

Yalew, E. Dawit, M. and Alemayehu, B. (2010).Investigation of causes of low academic performance of students in grade 8 regional examination in amhara region.

Yang,H. (2004). Factores affectingstudent burnout and academic achievement in multiple enrollment programs in Taiwan's technical-vocational colleges International Journal of Educational Development, 24283-301. 